\title{
構内重量積載車両用強制操舵台車の運動特性* (リンク式軸箱支持機構を有する台車の場合)
}

\author{
谷藤克也*1, 松嶋亨*2, 斎間 亨*3
}

\author{
Dynamic Behavior of a Heavy Haul Railway Vehicle \\ with Forced Steering Trucks Used in a Factory Yard \\ (In Case of Trucks with a Link-Type Mechanism for Axle Supporting)
}

Katsuya TANIFUJI, Toru MATSUSHITA and Toru SAIMA

\begin{abstract}
For a heavy haul railway vehicle negotiating tight curves in a factory yard, it is beneficial to employ forced steering trucks to reduce the lateral force between the wheel and rail. The forced steering truck has a wheelset supporting mechanism composed of hanging links and compressing ones for easy steering. The truck should also have a short wheelbase to meet special requirements in the yard. This paper deals with numerical analysis of dynamic behavior of the forced steering truck, in which running stability and the lateral force are examined, considering the wheelbase, the running speed, the longitudinal stiffness caused by the link mechanism, steering link stiffness and the leverage ratio. Results show that it is disadvantageous for both the running stability and the curving behavior to use a short wheelbase, and that the decrease of the steering link stiffness and the increase of the running speed also have disadvantageous effects on the curving performance. It is important for trade-off between the running stability and the curving behavior to select proper values for the longitudinal stiffness of the link mechanism and the leverage ratio.
\end{abstract}

Key Words : Railway, Forced Vibration, Stability, Eigenvalue Analysis, Numerical Simulation, Forced Steering Truck, Curve Negotiation, Wheel/Rail Lateral Force

\section{1. 緒}

一般に鉄道車両の曲線通過時には, 横圧およびレー ル・車輪フランジの摩耗が問題となる，この問題を解 決する方法として, 強制操舵台車の適用が報告されて いる(1)(2). 一方, 工場等の構内急曲線を走行する重量積 載の産業用車両においても，このような傾向が著しく 現れる場合があり，そこでも対策として強制操舵台車 の応用が考えられている.しかし，このような構内専 用の重量積載車両の中には, 構内運行での特殊用途に より輪軸間距離 (以下では軸距という)が短く構成され ているため, 軸ばねを取付けるための軸箱支持スペー スがとれない車両が存在する，このような車両は軸箱 が台車枠に直接取付けられた構造となっており, 操舵 を行うことが困難である。そこで，この問題を解決す るため，わずかなスペースで軸箱を支持することので きるリンク式軸箱支持機構をもつ強制操舵台車が提案 された ${ }^{(3)}$.この台車は, 釣りリンクおよび押しリンク

* 1994 年 9 月 21 日 東北支部石巻地方講演会および 1994 年 12 月 7 日 鉄道技術連合シンポジウムにおいて講演, 原稿 受付 1994 年 11 月 18 日.

*1 正員, 新潟大学工学部 (E950-21 新潟市五十嵐 2 の町 8050).

*2 学生員, 新潟大学大学院.

*3 正員, (株) 東芝 ( 183 府中市東芝町 1 番地).
と呼ばれるリンク機構により台車前後の軸箱が支持さ れており，その軸箱を操舵りンクで連結することによ り操舵を可能としている。しかし，このような特殊な 軸箱支持機構をもつ台車はこれまでになく，このよう な台車の運動特性については把握されていない.

そこで本研究では，上記のリンク式軸箱支持機構を 採用した重量積載車両用強制操舵台車について, 特殊 用途による制限の有無によって想定される二つの軸距 に着目し, 各車両パラメータが走行安定性と曲線通過 性能の二つの運動特性に及ほす影響について, 固有值 解析および数值シミュレーションにより検討を行う。

\section{2. 強制操舵台車を有する 重量積裁車両のモデル化}

$2 \cdot 1$ 記号の説明本報で用いるおもな記号は次 のとおりである.

$y_{B}, y_{T n}, y_{W i}$ : 左右動変位 (添字 $B$ は車体, $T$ は台車, $W$ は輪軸を表し, $n$ は台車番号 $1 ・ 2, i$ は輪 軸番号 $1 \sim 4$, 以下も同じ)

$\psi_{B}, \psi_{T n}, \psi_{W i}: \exists$ 角変位

$\phi_{B}, \phi_{T n}:$ ロール角変位

$\theta_{L n}:$ 操舵リンクの回転角

$m_{B}, m_{H}:$ 車体, 積載物の質量 
$m_{B H}:$ 車体と積載物の総合質量 $\left(=m_{B}+m_{H}\right)$ $m_{T}, m_{W}, m_{L}:$ 台車枠, 輪軸, 操舵リンクの質量 $k_{2 x}, k_{2 y}, k_{2 z}$ : 枕ば权の前後, 左右, 上下㴊性 $c_{2 y}, c_{2 z}$ : 枕ばねの左右, 上下減衰係数

$k_{1}, k_{W x}, k_{W y}: 1$ 輪軸当たりの軸ばね上下剛性, 軸箱前 後および左右支持剛性

$c_{1}: 1$ 輪軸当たりの軸ばねダンパの減衰係数 $k_{L U}, k_{L L}:$ 上部扔よび下部操舵リンクばねの剛性 $i_{B z}, i_{T z}, i_{W z}$ : 車体, 台車枠, 輪軸のヨーイング慣性半 径 $i_{B x}, i_{\tau x}:$ 車体, 台車枠のローリング慣性半径

$i_{L}:$ 操舵リンクの慣性半径

$2 b, 2 b_{1}, 2 b_{2}, 2 b_{3}$ : 車輪-レール間接触点, 軸ばね, 枕ば

ね, 操舵リンクの左右間隔

$b_{s}$ : 心孟回転摩擦力の等価的左右間隔の半分

$b_{F}:$ 輪軸中心からフランジ接触点の左右間隔

$l_{L U}, l_{L L}$ : 操舵機構垂直レバーの台車取付位置から上

部抢よび下部操舵リンクまでの距離

$2 l_{T}, 2 a$ : 台車中心間距離, 台車内輪軸間距離

$h_{T}:$ 車軸中心から台車枠重心までの高さ

$h_{A}$ : 台車枠重心から枕ばね中心までの高さ

$h_{A B}:$ 枕ばね中心から車体重心までの高さ

$r, \gamma:$ 車輪の転動半径, 踏面のこう配

$\delta:$ フランジ遊間

$\mu_{s}, 2 W$ : 心正の摩擦係数, 荷重 $\left(W=m_{B H} g / 4, g\right.$ は重 力加速度)

$k_{R}:$ : ルの有効横剛性

$f_{j i}$ : 飽和を考慮した非線形クリープ係数

$(j=1:$ 縦, $2:$ 横 $)$

$P:$ 輪重 $\left[=\left(m_{B H}+2 m_{T}+2 m_{L}+4 m_{W}\right) g / 8\right]$

$T_{W y i}, M_{w z i}:$ クリープよる横方向の力, $\exists$ 一方向の
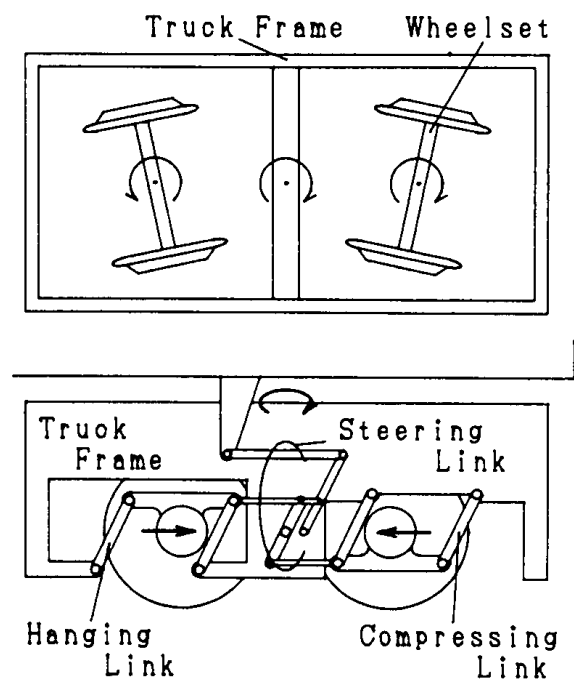

図 1 重量積载車両用強制操舵台車

$$
\text { モーメント }
$$

$V, v:$ 走行速度 (時速および秒速)

$F_{C F B}, F_{C F T n}, F_{C F W_{i}}$ : 車体, 台車枠, 輪軸に作用する遠 心力

$F_{R i}, F_{F i}:$ レール反力, フランジ摩擦力

$R_{i}, S_{i}$ : 各輪軸位置における曲線半径, スラック

$2 \cdot 2$ 重量樌载車両用強制操舵台車 図 1 にリン ク式の軸箱支持機構をもつ強制操舵台車を示す。この 台車は，軸箱の支持に釣りリンクと押しリンクの組合 せからなるリンク式軸箱支持機構を採用することによ り，わずかなスペースで軸箱を支持することを可能と している.これにより，軸箱支持スペースの制限を受 ける重量積載車両に対しても操舵機構の付加が可能と なる.この軸箱支持機構は, その構造上, 釣りリンク側 には軸箱を中心位置に戻そうとする復元力が作用し, また，押しリンク側には軸箱の変位をさらに大きくす る不安定力が作用する。それぞれ単独では操舵の妨げ となる力であるが, 両者を操舵リンクで連結すること により, 互いの力が相殺され，操舵を容易なものとし ている.この台車の操舵方式は，一般的な強制操舵台 車と同様であり，台車が旋回することで操舵リンクが 台車枠上の支点を中心に回転し, その回転角に応じた 操舵角が操舵リンクを介して輪軸に伝えられるボギー 角連動式と呼ばれるものである。

$2 \cdot 3$ モテル化 釣りリンク側のリンク式軸箱支 持機構の概略を図 2 に示す. 軸箱が $x_{H L}$ だけ変位した ときの支持リンクのなす角度を $\theta \fallingdotseq x_{H L} / l_{H L}$ とし, ここ に上下方向の荷重 $P_{V}$ が作用したとすると, 軸箱には 図 2 中のベクトル図に示す復元力 $P_{V} \tan \theta$ が作用す る.この復元力から軸箱の変位 $x_{H L}$ に対する軸箱の前 後支持剛性 $k_{H L}$ が次式で与えられる.

$$
k_{H L}=P_{V} \tan \left(x_{H L} / l_{H L}\right) / x_{H L} \fallingdotseq P_{V} / l_{H L}
$$

また，押しリンク側の不安定力もこれと同様な考えで 負の軸箱前後支持剛性 $k_{C L}$ として表すことができる.

$$
k_{C L} \fallingdotseq-P_{v} / l_{C L}
$$

これら二つの前後支持岡性を用いることにより次式で 表される等価的な軸箱前後支持剛性 $k_{W x}$ が前・後両軸

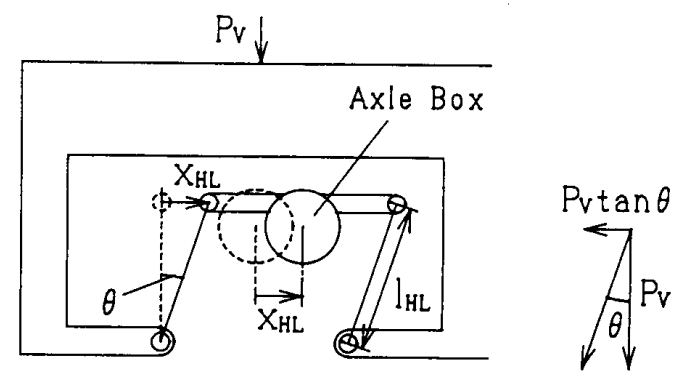

図 2 リンク式軸箱支持機構 (釣りリンク側) 

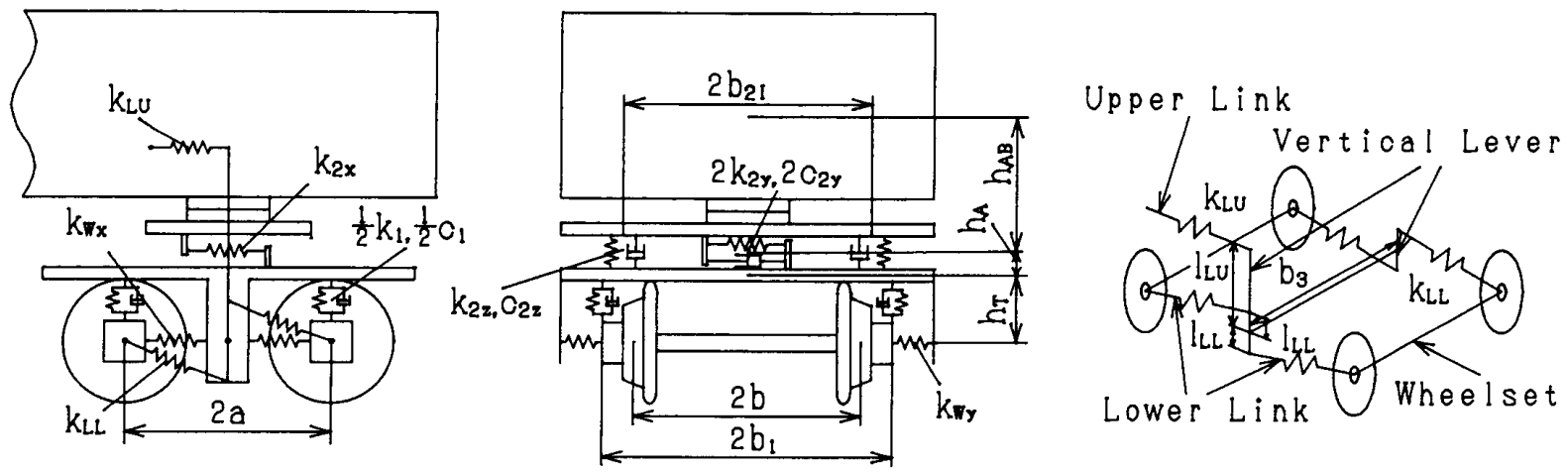

図 3 強制操舵台車を備えた重量積載車両

に等しく作用すると考えることができる.

$$
k_{W x}=\left(k_{H L}+k_{C L}\right) / 2
$$

したがって，てこ長さ $l_{H L}$ と $l_{C L}$ が等しい場合は $k_{W x}$ $=0$ となる.ここでは, $k_{W x}=0$ を検討の基本值とする.

リンク式軸箱支持機構を備えた強制操舵台車のモデ ル化を図 3 に示す.リンク式の軸箱支持機構は式 (3) の $k_{W x}$ を用いることにより一般的な一次ばね系とし てモデル化できる、モデルの運動自由度は，車体と前・ 後の台車でそれぞれ左右動，ヨー，ロール，4本の輪 軸で左右動とヨー, そして前・後台車における操舵レ バーの回転角の計 19 自由度である. また, 実際の走行 条件である積載状態を考慮して, 車体と積載物の総合 質量 $m_{B H}$ を用いて検討を行う。

$2 \cdot 4$ 曲線走行の影響 曲線走行シミュレーショ ンでは座標系を軌道中心に沿ってとるため, 車体一台 車間および台車一輪軸間の静的相対ヨー角を考慮する 必要がある。また，軌道中心位置に対する内・外軌側の 速度差のため, 内軌側で $-b / R_{i}$, 外軌側で $b / R_{i}$ の綐 滑り率が考慮される.

緩和曲線中での各輪軸位置における曲率 $1 / R_{i} お よ$ びスラック $S_{i}$ の変化は次式で表される.

$$
\begin{aligned}
& 1 / R_{i}=\left[\sin \left(x_{i} / X_{T C}-1 / 2\right) \pi+1\right] / 2 R_{0} \\
& S_{i}=S_{0}\left[\sin \left(x_{i} / X_{T C}-1 / 2\right) \pi+1\right] / 2 \cdots
\end{aligned}
$$

ここで, $R_{0}, S_{0}$ は定常円曲線内での曲線半径およびス ラック， $x_{i}$ は各輪軸の緩和曲線入口からの $x$ 軸方向 の距離, $X_{T C}$ は緩和曲線長を表す。台車枠重心位置に おける曲線半径は前・後輪軸における值の平均值 $R_{T n}$ とし, 車体重心位置における值は, 全軸の平均値 $R_{B}$ とする。これにより各質量に対する遠心力は次式で表 される。

$$
\begin{aligned}
& F_{C F B}=m_{B H} v^{2} / R_{B}, \quad F_{C F T n}=m_{T} v^{2} / R_{T n}, \\
& F_{C F W i}=m_{W} v^{2} / R_{i}
\end{aligned}
$$

$2 \cdot 5$ 非線形要榇 曲線走行の数值シミュレーシ ヨンを行う際には以下の非線形要素(4)(5) が考慮され
る。

（1）台車旋回抵抗モーメント本台車は大径心 皿方式であり，台車の旋回に対しては，心血部の摩擦 モーメント $M_{S}\left(=2 b_{s} \mu_{S} W\right)$ と枕ばねの前後剛性 $k_{2 x}$ に よるモーメントが直列に抵抗モーメント $M_{T n}$ として 作用する。

（a） 心㿼の滑りがない場合

$$
\begin{aligned}
& M_{T n}=2 k_{2 x} b_{2 x}^{2} \Delta \psi_{b n} \\
& \Delta \psi_{b n}=\left[\phi_{T n}-2 l_{T} /\left(R_{i}+R_{(i+1)}\right)\right]-\phi_{B}-\phi_{S n}
\end{aligned}
$$

ここで, $\Delta \psi_{b n}$ は枕ばねのヨーたわみ角， $\psi_{S n}$ は心血の 滑り角である。このとき $\left|M_{I n}\right| \leqq M_{S}$ の関係がある。 た， $n=1$ では $i=1, n=2$ では $i=3$ を用いる.

(b) 心血の滑りがある場合

$$
M_{T n}= \pm M_{S}
$$

このとき，枕ばねのヨーたわみ角は式（９）に示す最大 値となる。

$\Delta \psi_{b \max }=M_{s} / 2 k_{2 x} b_{2 x}^{2}$

（2）車輪・レール間のクリープカクリープカ 飽和特性として指数 1.5 の Lévi-Chartet $の$ 式(6) を使 用する。これにより,クリープによる横方向の力 $T_{w y i}$ とヨー方向のモーメント $M_{W z i}$ は次式となる.

$$
\begin{aligned}
T_{W y i} & =-2 f_{2 i}\left(\dot{y}_{W i} / v-\phi_{W i}\right) \cdots \cdots \cdots \cdots \cdots \cdots \cdots \\
M_{W z i} & =-2 f_{1 i}\left[(\gamma b / r) y_{W i}+\left(b^{2} / v\right) \dot{\psi}_{W i}-b^{2} / R_{i}\right]
\end{aligned}
$$

（3）フランジ反力 輪軸の左右変位がフランジ 遊間 $\delta$ とスラック $S_{i}$ (内軌側に付加) からなる可動範 冊を超えると, 車輪フランジがレール側面と接触し, レール反力 $F_{R i}$ とフランジ摩擦力 $F_{F i}{ }^{(7)}$ が発生する. レール反カは次式で与えられる.

(a) 右回り曲線

$$
\begin{aligned}
& \left.\begin{array}{ll}
F_{R i}=k_{R}\left(y_{w_{i}}-\delta\right) & : y_{W_{i}}>\delta \\
F_{R i}=k_{R}\left(y_{w_{i}}+\delta+S_{i}\right) & : y_{w_{i}}<-\delta-S_{i}
\end{array}\right\} \\
& F_{R i}=0 \quad:-\delta-S_{i} \leqq y_{W i} \leqq \delta
\end{aligned}
$$


(b) 左回り曲線

$$
\left.\begin{array}{ll}
F_{R i}=k_{R}\left(y_{W i}-\delta-S_{i}\right) & : y_{W i}<\delta+S_{i} \\
F_{R i}=k_{R}\left(y_{W i}+\delta\right) & : y_{W i}>-\delta \\
F_{R i}=0 & :-\delta \leqq y_{w i} \leqq \delta+S_{i}
\end{array}\right\}
$$

また, フランジ摩擦力はフランジ角度 $\alpha$ の場合, 次式で与えられる.

$$
F_{F i}=\mu\left|F_{R i}\right| \sin \alpha
$$

$2 \cdot 6$ 運動方程式 図 3 に示した車両の解析モデルから次の運動方程式が導出される。ここで,

$D=d / d t, \quad D^{2}=d^{2} / d t^{2}, \quad J_{B z}=m_{B H} i_{B z}^{2}, \quad J_{B x}=m_{B H} i_{B x}^{2}$,

$J_{T z}=m_{T} i_{T z}^{2}, \quad J_{T x}=m_{T} i_{T x}^{2}, \quad J_{W z}=m_{W} i_{W z}^{2}, \quad J_{L}=m_{L} i_{L}^{2}$

である。

車体の左右動, ヨー, ロールに関する三つの式

$$
\begin{aligned}
& m_{B H} D^{2} y_{B}+2\left(k_{2 y}+c_{2 y} D\right)\left[2 y_{B}+2 h_{A B} \phi_{B}-y_{T 1}-y_{T 2}+h_{A}\left(\phi_{T 1}+\phi_{T 2}\right)\right]=F_{C F B} \ldots \ldots \ldots \ldots \ldots \ldots \ldots \ldots \ldots \ldots \ldots \ldots \ldots \ldots \ldots \ldots \ldots \ldots \\
& J_{B z} D^{2} \psi_{B}+2 l_{T}\left(k_{2 y}+c_{2 y} D\right)\left[2 l_{T} \psi_{B}-y_{T 1}+y_{T 2}+h_{A}\left(\phi_{T 1}-\phi_{T 2}\right)\right] \\
& \quad+k_{L U} b_{3}^{2}\left\{2 \psi_{B}+l_{L U} \theta_{L 1} / b_{3}+l_{L U} \theta_{L 2} / b_{3}-\left[\phi_{T 1}-2 l_{T} /\left(R_{1}+R_{2}\right)\right]-\left[\phi_{T 2}+2 l_{T} /\left(R_{3}+R_{4}\right)\right]\right\}=M_{T 1}+M_{T 2}
\end{aligned}
$$

$$
J_{B x} D^{2} \phi_{B}+2 h_{A B}\left(k_{2 y}+c_{2 y} D\right)\left[2 y_{B}+2 h_{A B} \phi_{B}-y_{T 1}-y_{T 2}+h_{A}\left(\phi_{T 1}+\phi_{T 2}\right)\right]
$$$$
+2 b_{2}^{2}\left(k_{2 z}+c_{2 z} D\right)\left(2 \phi_{B}-\phi_{T 1}-\phi_{T 2}\right)=0
$$

2 台車の左右動, ヨー, ロールに関する六つの式,

$$
\begin{aligned}
& m_{T} D^{2} y_{T n}-2\left(k_{2 y}+c_{2 y} D\right)\left(y_{B} \pm l_{T} \phi_{B}+h_{A B} \phi_{B}-y_{T n}+h_{A} \phi_{T n}\right) \\
& +2 k_{W y}\left(2 y_{T n}+2 h_{T} \phi_{T n}-y_{W i}-y_{W(i+1)}\right)=F_{C F T n} \\
& J_{T z} D^{2} \psi_{T n}+2 k_{W x} b_{1}^{2}\left[2 \psi_{T n}-\left(\phi_{W i}-a / R_{i}\right)-\left(\phi_{W(i+1)}-a / R_{(i+1)}\right)\right] \\
& +2 k_{W y} a\left(2 a \psi_{T n}-y_{W_{i}}+y_{W(i+1)}\right)+2 k_{L L} b_{3}^{2}\left[2 \psi_{T n}-\left(\psi_{W_{i}}-a / R_{i}\right)-\left(\psi_{W(i+1)}-a / R_{(i+1)}\right)\right] \\
& -k_{L U} b_{3}^{2}\left\{\phi_{B}+l_{L U} \theta_{L n} / b_{3}-\left[\phi_{T n} \mp 2 l_{T} /\left(R_{i}+R_{(i+1)}\right)\right]\right\}=-M_{T n} \\
& J_{T x} D^{2} \phi_{T n}+2 h_{A}\left(k_{2 y}+c_{2 y} D\right)\left(y_{B} \pm l_{T} \psi_{B}+h_{A B} \phi_{B}-y_{T n}+h_{A} \phi_{T n}\right) \\
& -2 b_{2}^{2}\left(k_{2 z}+c_{2 z} D\right)\left(\phi_{B}-\phi_{T n}\right)+2 k_{W y} h_{T}\left(2 y_{T n}+2 h_{T} \phi_{T n}-y_{W i}-y_{W(i+1)}\right)+2 b_{1}^{2}\left(k_{1}+c_{1} D\right) \phi_{T n}=0
\end{aligned}
$$

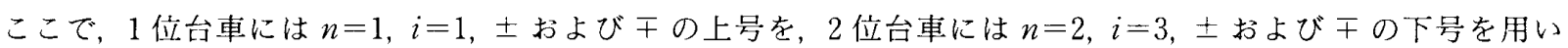
る.

4 輪軸の左右動, ヨーに関する八つの式

$$
\begin{aligned}
& m_{W} D^{2} y_{W i}-2 k_{W y}\left(y_{T n}+h_{A} \phi_{T n} \pm a \psi_{T n}-y_{W i}\right)=T_{W y i}-F_{R i}+F_{C F T n} \\
& J_{W z} D^{2} \psi_{W i}-2 k_{W x} b_{1}^{2}\left[\psi_{T n}-\left(\psi_{W i} \mp a / R_{i}\right)\right]-2 k_{L L} b_{3}^{2}\left[\psi_{T n} \pm l_{L L} \theta_{L n} / b_{3}-\left(\phi_{W i} \mp a / R_{i}\right)\right]=M_{W z i} \pm b_{F} F_{F i}
\end{aligned}
$$

ここで 1 位， 2 位輪軸 $(i=1,2)$ では $n=1,3$ 位， 4 位輪軸 $(i=3,4)$ では $n=2$ となる.式(21)の土, 式(22)左辺の干 については, $i=1,3$ で上号, $i=2,4$ で下号であり, 式(22)左辺第 3 項の \pm の $i=1,4$ で上号, $i=2,3$ で下号を用 いる。また, 式(22)右辺の土についてはフランジ接触しているのが進行方向右側車輪のときに上号, 左側車輪のと きに下号を用いる.

操舵りンクの回転角に関する式

$$
\begin{aligned}
& J_{L} D^{2} \theta_{L n}+k_{L U} l_{L U} b_{3}\left\{\psi_{B}+l_{L U} \theta_{L n} / b_{3}-\left[\phi_{T n} \mp 2 l_{T} /\left(R_{i}+R_{(i+1)}\right)\right]\right\} \\
& \quad+2 k_{L L} l_{L L} b_{3}\left[2 l_{L L} \theta_{L n} / b_{3} \mp\left(\phi_{W i}-a / R_{i}\right) \pm\left(\phi_{W(i+1)}+a / R_{(i+1)}\right)\right]=0
\end{aligned}
$$

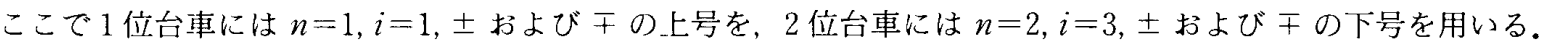

計算で使用した車両諸元の基本值は以下の値である。

$m_{B}=80.4 \mathrm{t}, \quad m_{H}=50 \mathrm{t}, \quad m_{\tau}=4.72 \mathrm{t}, \quad m_{W}=3.57 \mathrm{t}, \quad m_{L}=1.00 \mathrm{t}, \quad i_{B z}=4.67 \mathrm{~m}$,

$i_{B x}=1.06 \mathrm{~m}, \quad i_{T z}=0.98 \mathrm{~m}, \quad i_{T z}=0.84 \mathrm{~m}, \quad i_{W z}=0.69 \mathrm{~m}, \quad k_{1}=22.8 \mathrm{MN} / \mathrm{m}$,

$k_{W y}=3.92 \mathrm{MN} / \mathrm{m}, \quad k_{W x}=0.0 \mathrm{MN} / \mathrm{m}, \quad k_{2 x}=17.9 \mathrm{MN} / \mathrm{m}, \quad k_{2 y}=17.9 \mathrm{MN} / \mathrm{m}, \quad k_{2 z}=20.0 \mathrm{MN} / \mathrm{m}$,

$k_{L U}=2675 \mathrm{MN} / \mathrm{m}, \quad k_{L L}=321 \mathrm{MN} / \mathrm{m}, \quad c_{1}=140.8 \mathrm{kN} \cdot \mathrm{s} / \mathrm{m}, \quad c_{2 y}=120 \mathrm{kN} \cdot \mathrm{s} / \mathrm{m}, \quad c_{2 z}=126.6 \mathrm{kN} \cdot \mathrm{s} / \mathrm{m}$,

$b=0.766 \mathrm{~m}, \quad b_{1}=1.04 \mathrm{~m}, \quad b_{2}=0.58 \mathrm{~m}, \quad b_{3}=1.24 \mathrm{~m}, \quad b_{s}=0.115 \mathrm{~m}, \quad b_{F}=0.75 \mathrm{~m}$, 


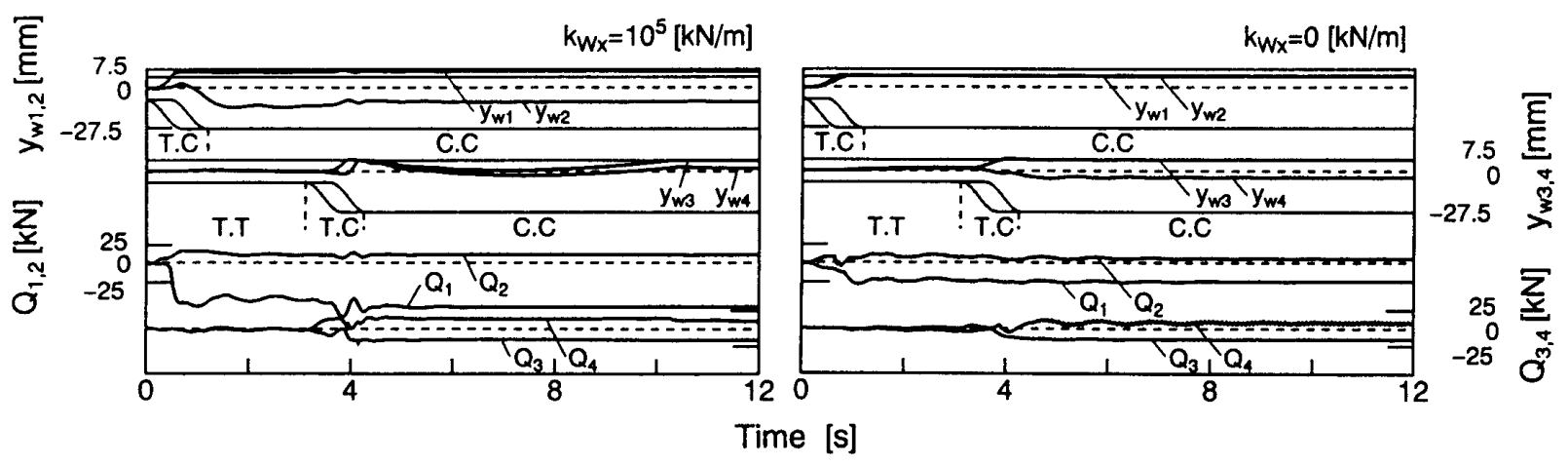

(a) 操舵なし

(b) 操舵あり

図 4 シミュレーション結果の例

$l_{L U}=0.56 \mathrm{~m}, \quad l_{L L}=0.174 \mathrm{~m}, \quad l_{T}=6.5 \mathrm{~m}$,

$a=0.72 \mathrm{~m}, \quad h_{T}=0.083 \mathrm{~m}, \quad h_{A}=0.067 \mathrm{~m}$,

$h_{A B}=1.52 \mathrm{~m}, \quad r=0.43 \mathrm{~m}, \quad \gamma=0.1, \quad \mu=0.2$,

$\mu_{S}=0.06, \quad k_{R}=19.6 \mathrm{kN} / \mathrm{m}, \quad P=19.3 \mathrm{t}$

線形のクリープ係数 $f_{j}$ は文献 $(8)$ の Carter および Cain の式

$$
f_{j[\mathrm{kgf}]}=465 \sqrt{r_{[\mathrm{mm}]} P_{[\mathrm{kgf}]}}
$$

を用いて， $f_{1}=f_{2}=13.2 \mathrm{MN}$ を使用する。

\section{3. 数 值 解 析}

3・1 走行安定性 走行安定性は固有值解析によ り検討する，ただし，固有值解析は線形計算であるた め $2 \cdot 3$ 節で述べた曲線の影響と $2 \cdot 4$ 節の非線形要素は 考慮しない. 走行安定性の評価は, モデルの運動自由 度に対応する各振動モードの固有値 $\lambda_{m}=\alpha_{m}+j \omega_{m}$ か ら算出される減衰比 $\zeta_{m}$ によって行われる.

$$
\zeta_{m}=-\alpha_{m} / \sqrt{\alpha_{m}^{2}+\omega_{m}^{2}} \quad(m=1 \sim 19)
$$

この $\zeta_{m}$ が負の值をとる場合, そのモードは不安定で あることを示す，検討の対象としては，低速から不安 定化の可能性がある車体の上心ロール $\phi_{B U}$, 下心ロー ル $\phi_{B L}, \exists ー \phi_{B}$ の三つの振動モードを取扱う。

\section{$3 \cdot 2$ 曲線通過性能曲線通過性能は曲線走行の} 数值シミュレーションにより検討する.図 4(a), (b) に曲線通過シミュレーションの一例を示す。図 4(a) は従来形の操舵がない場合のものであり, 図 4(b)は 強制操舵機構が付加された場合である。速度は構内で の標準とされる $15 \mathrm{~km} / \mathrm{h}$, 軌道条件は, 曲線半径 140 $\mathrm{m}$, フランジ遊間 $7.5 \mathrm{~mm}$ ，スラック $20 \mathrm{~mm}$ である。 図 4(a)，(b)はそれぞれ第 1 輪軸から第 4 輪軸まで の各輪軸の左右変位と横圧の関係を示したものであ る. $y_{W_{1}}$ から $y_{W_{4}}$ は各輪軸の左右変位であり, $Q_{1}$ から
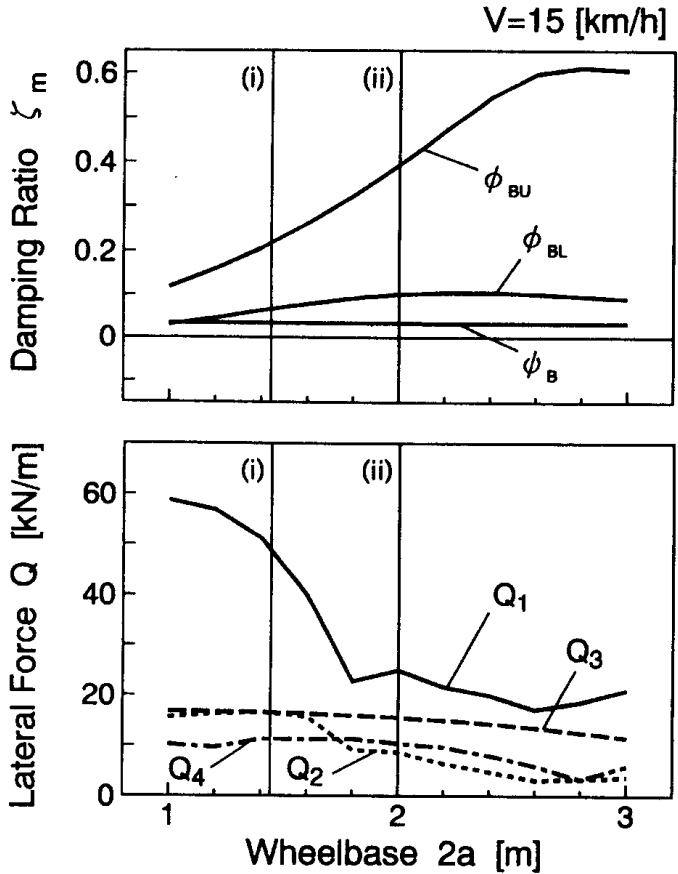

図 5 軸距が減衰比と横圧に及ほす影響

$Q_{4}$ は同様に各輪軸の横圧 $\left(Q_{i}=F_{R i}-T_{W y i} / 2\right)$ を示す. 各輪軸は直線軌道 (T. T), 緩和曲線 (T. C), 定常円曲 線 (C. C)の三つの区間を通過する。図 4(a ) と (b)を 比較すると，強制操舵による横圧の低減は第 1 輪軸に おいて顕著であり，操舵なしの場合の第 1 輪軸の横圧 $Q_{1}$ に対し，操舵ありの場合は大幅に隇少している。ま た，他の輪軸でもわずかではあるが，横圧の低減が見 られ，横圧の低隇にとって強制操舵が有効であること が示される.

\section{4. 計 算 結 果}

$4 \cdot 1$ 軸距 $2 a$ の影留 図 5 の上図は車体の各振 動モードの減衰比 $\zeta_{m}$ に対する軸距 $2 a$ の影響を示し 
たものである. $3 \mathrm{~m}$ までの軸距の増加に対し $\zeta_{m}$ は増加 し, 約 $2.6 \mathrm{~m}$ で一定の值になる。特に上心ロール $\phi_{B U}$ のモードでその増加傾向は強くなっている．図５下図 は軸距を変化させてシミュレーションを行ったときの 定常円曲線内での各輪軸の最大横圧の絶対値をまとめ たものである．軸距の影響は第 1 輪軸において顕著で あり，軸距の増加に伴い軸距の短い範囲では，横圧の 急激な減少が見られ，その後は緩やかに減少する。し かし，軸距が約 $2.6 \mathrm{~m}$ を超えて大きくなると逆に横圧 は増加する傾向が見られる。

以下の計算では, 本研究で対象としている軸距が短 い場合の（i ） $2 a=1.44 \mathrm{~m}$ と, 軸距の支持にリンク式 ではなく軸ばね式の軸箱支持機構を採用することので きる (ii) $2 a=2.00 \mathrm{~m}$ の強制操舵台車について検討す る.

$4 \cdot 2$ 軸箱前後支持剛性 $\boldsymbol{k}_{\boldsymbol{w} x}$ の影響 図 6 上図 は，車体の各振動モードの減衰比 $\zeta_{m}$ に対する軸箱前 後剛性 $k_{W x}$ の影響を示したものである.リンク式軸箱 支持機構で基本值とみなされる $k_{W x}=0$ の場合には不 安定化するモードは存在しない。さらに, $k_{W x}$ が負の 值になってもある程度までは安定性が保たれる。これ は，軸箱が $k_{W x}$ のみでなく操舵リンクばねとの総合剛 性によって支持されていることに起因する．図6下図 は，横圧が最も大きい第 1 輪軸 $Q_{1}$ に対する $k_{W x}$ の影 響をまとめたものである.リンク式の軸箱支持機構で 基本とみなせる $k_{W x}=0$ の値において, 軸距 $2 a$ の短い 場合, 第 1 輪軸の横圧低減は小さいものとなってい
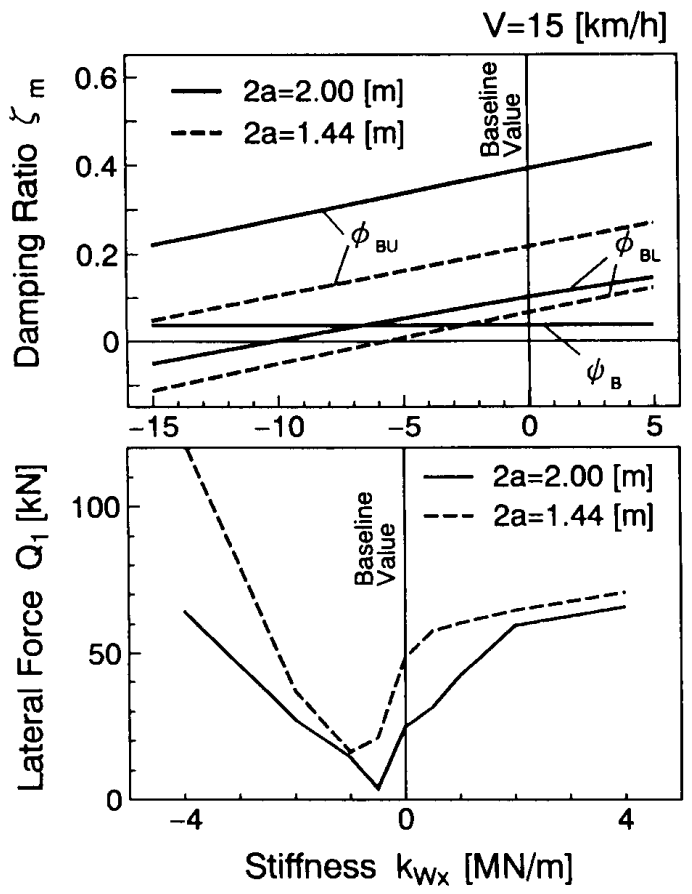

図 6 軸箱前後剛性が隇衰比と横圧に及ほすす影響
る.しかし， $k_{W x}$ の值がわずかに負の値になると，軸距 の短い場合でも横圧が大きく隇少し操舵効果が現れ る.

$4 \cdot 3$ 操舵リンク剛性 $\boldsymbol{k}_{\boldsymbol{L} U}$ の影響 図 7 は車体の 各振動モードの減衰比 $\zeta_{m}$ おる゙第 1 輪軸の横圧 $Q_{1}$ に対する操舵リンク剛性 $k_{L U}$ の影響を示したもので ある。一般にある程度までの $k_{L U}$ の増加は操舵効果を 向上させる，走行安定性については， $k_{L U}$ が小さい場 合は上心ロール $\phi_{B U} お よ ひ ゙ 下 心 ロ ー ル ~ \phi_{B L}$ のモード が不安定になるが, $k_{L U}$ が 100 から $10000 \mathrm{kN} / \mathrm{m}$ まで 増加するとかなりの減衰比の上昇が見られる。ささらに， $k_{L U}$ がそれ以上の值になると，どちらもほほ一定にな る.また, ヨー $\psi_{B}$ のモードに対しては $k_{L U}$ の影響は小 さい. 横圧に対する $k_{L U}$ の影響としては, 軸距 $2 a$ が長 い場合では $k_{L U}$ が 100 から $1000 \mathrm{kN} / \mathrm{m}$ の範囲で横圧 は減少し，それ以上の範囲ではほぼ一定値を示すが， 軸距の短い場合には， $k_{L U}$ の影響は小さく $k_{L U}$ が増加 してもあまり横圧の減少は見られない。これは, 軸距 が長い場合には，前軸に作用するレール反力によるモ 一メントが大きくなり，台車の旋回，さらに，輪軸の 操舵が容易になるものと考える。なお，軸距の大小に よらず $k_{L U}$ をある程度 $\left(10^{5} \mathrm{kN} / \mathrm{m}\right)$ 以上大きくとれば $\zeta_{m} お よ ひ ゙ Q_{1}$ がほほ一定となることが示される。

$4 \cdot 4$ てこ比 $l_{L L} / l_{L U}$ の影響 車体の各振動モー ドの減衰比 $\zeta_{m}$ および第 1 輪軸の横压 $Q_{1}$ に対する操 舵りンクのてこ比 $l_{L L} / l_{L U}$ の影響を図 8 に示す.てこ比 が大きくなるほど操舵角が大きくなり, 操舵効果が向
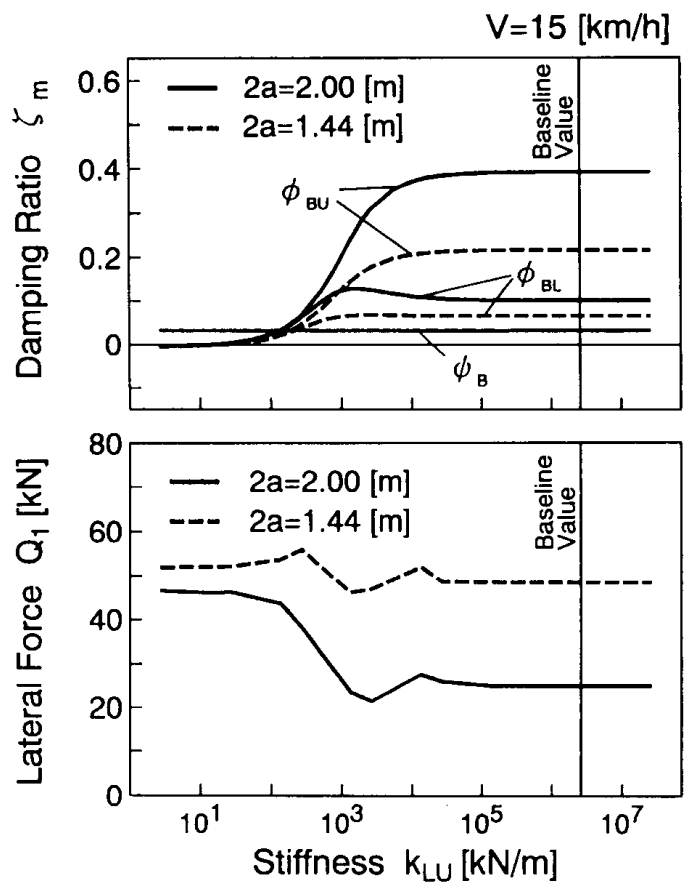

図 7 操舵リンク剛性が隇衰比と横圧に及ほす影響 

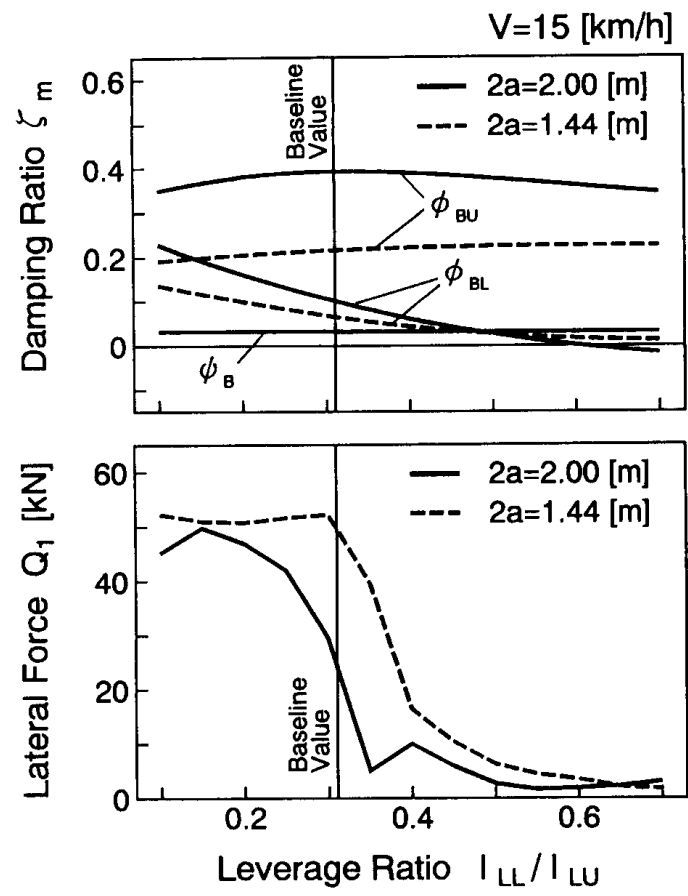

図 8 リンク比が隇衰比と横圧に及ぽす影響

上する．走行安定性に対するてこ比の影響としては, $l_{L L} / l_{L U}$ の上昇に伴い，特に下心ロール $\phi_{B L}$ のモードで 不安定化の傾向が示される。 また, 曲線通過性能に対 しては, $l_{L L} / l_{L U}$ の值が $0.3 \sim 0.4$ の範囲で横圧の急激 な滅少が示される。なお，さらにリンク比を上げると 他の輪軸のほうで横圧が大きい状態になる。

以上により， $l_{L L} / l_{L U}$ は走行安定性と曲線通過性能に 相反する影響を与えるものであり， $l_{L L} / l_{L U}$ の選択が走 行安定性と曲線通過性能のトレードオフにとって非常 に重要であることが示される．また，検討で用いた基 本值の場合，特に軸距の短い場合に横圧がかなり大き いままであるため, 安定性が保たれる範囲で $l_{L L} / l_{L U}$ を増加させることが望ましい．

4.5 速度 $V$ の影艟 車体の各振動モードの減 衰比 $\zeta_{i}$ に対する速度 $V$ の影響を図 9 上図に示す。速 度の増加に対し上心口ール $\phi_{B U}$ と下心ロール $\phi_{B L}$ の モードの減衰比は減少傾向を示し, 特に $\phi_{B L}$ のモード は軸距 $2 a$ の短い台車で $40 \mathrm{~km} / \mathrm{h}$, 長い台車で $50 \mathrm{~km} /$ $\mathrm{h}$ の速度で不安定化する.つまり,ここでも軸距の短 い台車の安定性岻いことが示される。 また, 横圧に 対する速度の影響を図 9 下図に示す。構内での標準運 行速度 $15 \mathrm{~km} / \mathrm{h}$ を超えて $30 \mathrm{~km} / \mathrm{h}$ 程度までは操舵効 果により，横圧の増加傾向は緩やかであるが，それ以 上の速度になると遠心力の影響により操舵効果が打消 され横圧の増加傾向が強くなることが示される.

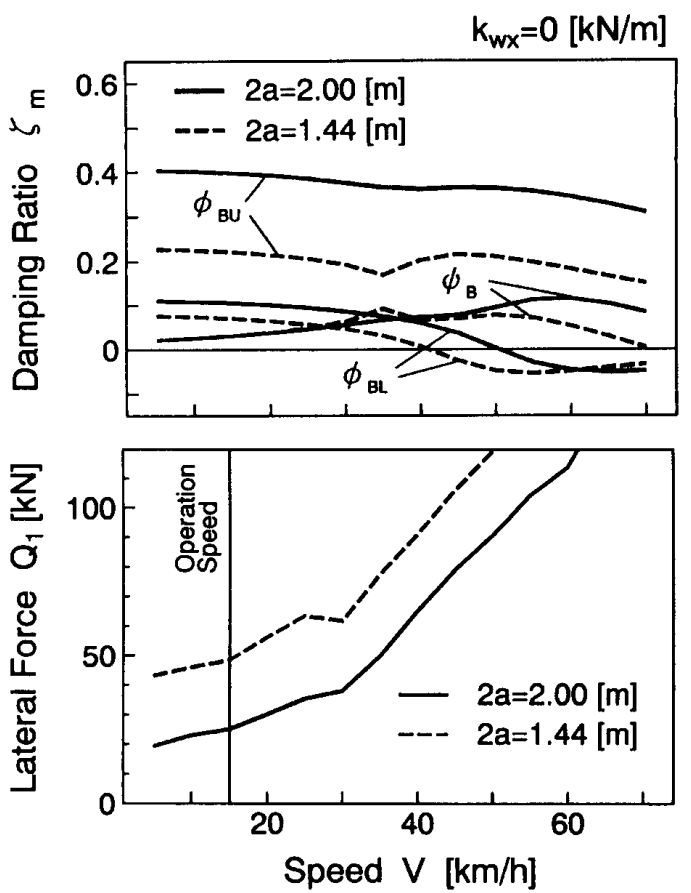

図 9 走行速度が減衰比と横圧に及活す影響

\section{5. 結焉}

リンク式軸箱支持機構を採用した強制操舵台車の運 動特性について検討を行い, 以下の結果を得た.

（1）検討の範囲内において輪軸間距離の長い場 合, 操舵機構の付加は, 走行安定性の向上および横圧 低減に効果が認められるが, 輪軸間距離が短くなると 走行安定性が低下し, 横圧も增大する傾向がある.

（2）操舵リンクばねの剛性があるため, 軸箱支持 の等価剛性 $k_{W x}$ が負の值, つまり軸箱支持の押しリン クによる不安定力がある程度まで大きな状態になって も走行は不安定化しない, また, $k_{w x}=0$ の場合, 軸間 距離の短い強制操舵台車は横圧の低隇効果があまり見 られないが, $k_{W x}$ がわずかに負の值になることで操舵 効果が現れる.

（3）上部操舵リンク剛性 $k_{L U}$ の増加に伴い減衰 比は上昇し, 横圧は低下するが, $k_{L U}$ の值をある程度 以上に大きくしても,さらに特性の改善にはならな い.

（4） $l_{L L} / l_{L U}$ は走行安定性と曲線通過性能に相反 する影響を与えるものであり， $l_{L L} / l_{L U}$ の選択は走行安 定性と曲線通過性能のトレードオフにとって重要であ る.

（5）走行速度の向上に伴い下心ロール $\phi_{B L}$ が不 安定化する傾向があり, 横圧も増大する. 


\section{文献}

（1）米田・広沢, 機論, 59-564, C(1993), 230.

（2）松尾・佐藤・石黑, 機構論, No. 930-42 (1993), 500.

（3）斎間，特竍公報，B $61 \mathrm{~F} 5 / 00 ， 7$ PA 912012，(199176266).
（4） 谷藤, 機論, 55-512, C(1989), 940.

（5）弘津・ほ加 3名，機論，49-446，C(1983)，1845.

（6） 松井, P-SC 64 分科会報告, No. 335 (1984-10)， 32 .

（7）松井，東急車両技報，37(1984)，2.

（8）谷口編，振動工学ハンドブック，(1976)，1160, 養賢堂 